\title{
Efficacy in treatment of subclinical cervical HPV infection without intraepithelial neoplasia: systematic review
}

\author{
Instituto Fernandes Figueira, Fundação 0 swaldo Cruz, Rio de Janeiro, B razil
}

\section{abstract}

CONTEXT: The treatment of the subclinical Human papillomavirus (HPV) infection of the uterine cervix is controversial.

OBJ ECTIVE: To assess the efficacy of any therapy for subclinical HPV infection of the cervix without intraepithelial neoplasia, via a search in the medical literature.

METHOD: W e performed a systematic review with a comprehensive reference search in Medline, LILACS, Excerpta M edica, AIDSLIN E, Popline, Cochrane Library and other authors' reference lists to identify experimental studies of therapy for subclinical HPV infection without intraepithelial neoplasia of the uterine cervix. In order to identify unpublished studies, we also contacted experts in the area, clinical trial registries, pharmaceutical industries, government and research institutions. We also searched on the Internet and in the book-ofabstracts of some medical conferences. The studies identified were masked and selected by inclusion criteria to help ascertain their internal validity. The data about regression or progression of HPV infection were extracted from the studies included.

RESULTS: We identified 67 studies related to the treatment of subclinical HPV infection without intraepithelial neoplasia of the uterine cervix. O nly five clinical trials matched the inclusion criteria and none demonstrated significant differences between the experimental group and the control group concerning regression of HPV infection (with or without CIN I) or progression to higher grades of CIN .

CONCLUSION: The evidence we found in the medical literature regarding the efficacy of any therapy for subclinical HPV infection without intra epithelial neoplasia of the uterine cervix was unsatisfactory.

KEY WORDS: HPV. Cervical Intraepithelial N eoplasia. Treatment. Systematic Review.

\section{INTRODUCTION}

The treatment of subclinical human papillomavirus $(\mathrm{HPV})^{1}$ infection is a matter of controversy. As defined by Reid et al (1982), in this kind of HPV infection, instead of producing an overt condyloma, a "macroscopic invisible, non-papilliferous epithelial hyperplasia" can be produced. Considering the high incidence of cervical cancer worldwide, it would be reasonable to try to treat all forms of HPV infection to prevent future cancer development. However, considering the high frequency of spontaneous regression of HPV infection and the lack of a specific antiviral drug, many experts follow these patients conservatively and treat cervical intraepithelial neoplasia (CIN), should it develop.

The goal of this paper is to search for evidence of efficacy of any treatment for subclinical HPV infection of the cervix when there is no concomitant CIN using a systematic review of the medical literature.

\section{METHODS}

\section{Study search}

A comprehensive search in the medical literature was performed, including both published and unpublished studies. Studies were identified using reference databases (Medline, Compact Medical Librarian-AIDSLINE, LILACS, Excerpta Medica, Popline and the Cochrane Library), other authors' reference lists, abstracts of studies presented in meetings related to cervical pathology, information from experts that work in the area, information from institutions that financially support clinical research, Clinical Tri- 
als Registries, government agencies, pharmaceutical companies and Internet sites.

In digital media, the search was carried out using terms related to uterine cervix, treatment and subclinical HPV infection (Table 1). The search period ranged from 1977 to March 1997, since the first studies linking HPV to cervical neoplasia date from 1977. Studies published in English, Spanish or Portuguese were included.

The studies identified were obtained and their methodology was assessed to verify their internal validity.

The criteria used to diagnose HPV infection varied between authors. Different diagnostic criteria were

Table 1 - The strategy used to search for related studies in Medline (applies only to Silverplatter 3.1)

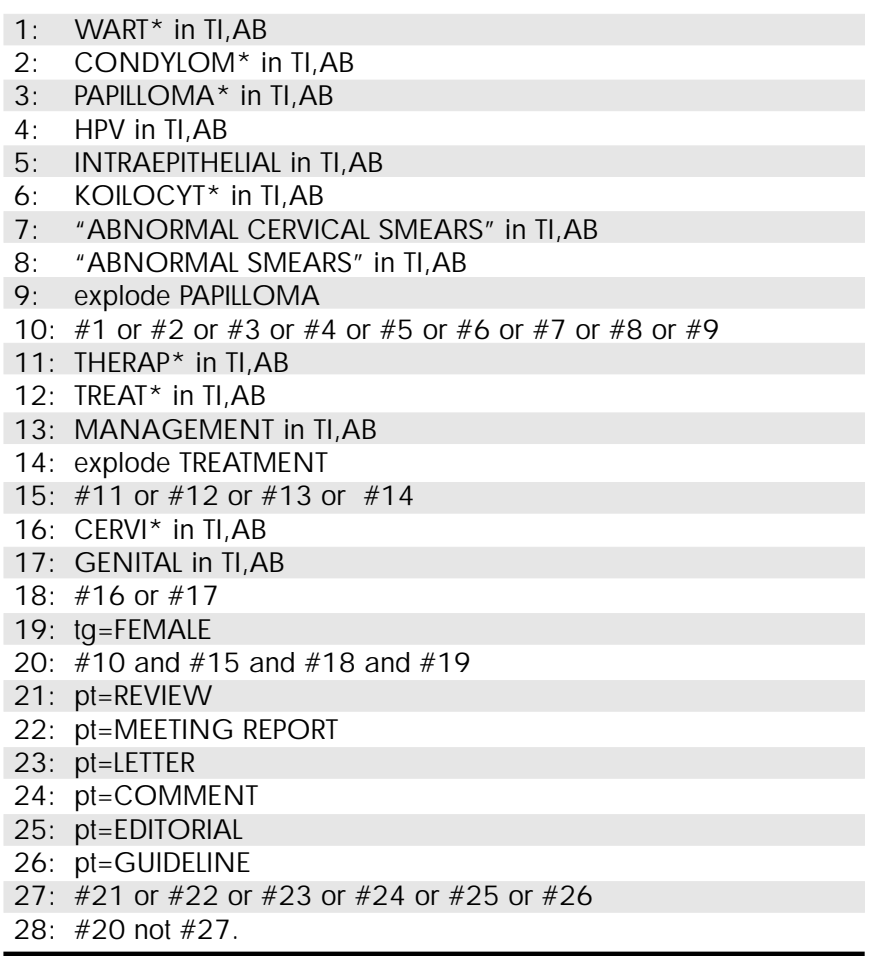

28:

Table 2 - Inclusion criteria (adapted from Guyatt et al 1993)

\begin{abstract}
GENERAL ASPECTS
- Study of treatment for subclinical HPV infection of the cervix without intraepithelial neoplasia (studies using the term "low grade lesion" published after 1990, were also considered).

- Complete investigation, with final results shown.
\end{abstract}

\section{METHODOLOGICAL ASPECTS}

- Randomized clinical trial, placebo-controlled.

- Identical and valid diagnostic methods used to identify infected women and to measure the results after intervention.

- Loss to follow-up of $10 \%$ or less.

- Follow-up period of at least one month.

- Intention-to-treat a nalysis.

- Experimental and control groups similar at entry into the study concerning age and other factors that could interact with any treatment modality. Differences need to have been checked prior to analysis.

- The groups must be treated and followed equally, apart from the experimental intervention. accepted if they were used consistently within a given study, i.e. used to both select patients and to determine outcome. This allowed us to include studies done prior to the availability of HPV-DNA detection methods and to avoid selection bias.

HPV infection diagnostic criteria included cytology, colposcopy, histology or a combination of these methods. Some of the more recent studies also used HPV-DNA detection methods in their analysis.

An instrument was built to assess the internal validity of each study and identify studies for selection, based on criteria adapted from Guyatt et al2-4 (Table 2). We assessed the reliability of this instrument between two of the present authors (FR \& SCF), assessing the internal validity of a sample of $15 \%$ of the studies identified, and concluding that it had good reliability. ${ }^{5-8}$

Each study was masked, with only its methodology section being assessable. Studies that met inclusion criteria had their data extracted, including sample size, treatment tested and treatment outcome in the experimental and control groups. Data was analyzed and synthesized but could not be combined because of differences in treatment modalities.

\section{RESULTS}

\section{Results of the study search}

Studies identified are listed in the Reference section (references 9 through 75) and a summary of the results of the study search from each source is shown in Table 3. Eight studies could not be obtained for review (references 9 through 16).

\section{Table 3 - Reference sources and their results} (number of studies identified)

\begin{tabular}{lcc}
\hline Reference sources* & $\begin{array}{c}\text { \# of identified } \\
\text { studies }\end{array}$ & $\begin{array}{c}\text { \# of non-obtained } \\
\text { studies }\end{array}$ \\
\hline M edline (alone) & 17 & 2 \\
Medline \& Excerpta M edica & 14 & - \\
M edline \& LILCS & 4 & 1 \\
Medline \& other authors' reference lists & 10 & - \\
M edline, Excerpta M edica \& & 4 & - \\
other authors' reference lists & 3 & 1 \\
Excerpta M edica (alone) & & \\
Excerpta M edica \& & 2 & - \\
other authors' reference lists & 1 & - \\
LLACS (alone) & 2 & - \\
LLACS \& other authors' reference lists & 1 & - \\
LLACS \& experts' information & 7 & 2 \\
O ther authors' reference lists (alone) & 7 & 2 \\
Abstracts of studies & 2 & $\mathbf{8}$ \\
presented in medical meetings & 2 & $\mathbf{6 7}$ \\
\hline Totals & &
\end{tabular}

* Reference sources that were used but did not identify studies include: Compact Library AIDS, Cochrane Library, Popline, Internet \& electronic journals, Clinical Trials Registries, government institutions, research sponsoring institutions, pharmaceutical companies. 


\section{Study selection}

Of the 59 studies obtained in their full version, 5 were included ${ }^{19-23}$ and 54 were excluded. ${ }^{17,18,24-75}$ The primary reason why studies were excluded was their study design (42 studies - 77\%). The remaining 12 (22\%) showed one of the following situations: four were clinical trials but were not placebo-controlled; two had more than $10 \%$ of patients lost to follow-up; one tested adjuvant therapy instead of primary therapy; one assessed the outcome differently in experimental and control groups; one analyzed patients with HPV without CIN together with patients with CIN I (published before 1990) or CIN II; one tested the therapy on clinically-expressed HPV infection; one reported only preliminary data; and in one we were not able to extract the information needed from it.

In Table 4 and in the following text we show a brief summary of the five studies that met the inclusion criteria. Two studies included at first were then excluded. The first one was the study by Yliskoski et al, $1991 .{ }^{17}$ They had studied a group of patients with HPV without CIN together with others with CIN. We wrote to one of the authors (KS) and he told us that the data was not available anymore. The other study was the one from Woodman et al, 1993. ${ }^{18}$ This study presents treatment outcomes from patients with progression risk and it was not stated how many patients had regression or progression. We wrote to the first author but we have not had any reply yet.

\section{B oothby et al., ${ }^{19} 1990$.}

This is a randomized clinical trial testing trichloroacetic acid (TCA) at 50\% concentration, applied to the cervix. Thirty-four women with biopsy-proven HPV infection of the cervix were randomly allocated to receive TCA or normal saline in a blinded fashion. The outcome was assessed 16 weeks after treatment. The treatment was considered a failure if there was evidence of HPV on Pap smear or biopsy. The text does not provide a similarities analysis between the groups after treatment allocation. Although the authors state that patients and investigators were blinded to the treatment allocation, there is a marked difference in cervix appearance after applying the two substances. The application of TCA turns the cervix surface white, as a result of chemical coagulation of its epithelium proteins and impairment in viewing the color of the stroma. If this had been reported in patient records, to the patient or kept in mind by the medical doctor, the blinding could have been impaired (potential source of assessment bias). When the first 15 patients in each group were analyzed, no differences were noted and the study was closed. No patients were lost to follow-up. Six women in the experimental group and two in the control group had undesirable side effects. Two women in the experimental group developed CIN I.

\section{Diakomanolis et al., ${ }^{20} 1990$.}

This study enrolled 452 women with biopsyproven HPV cervical infection without CIN. The authors report that "patients were allocated randomly under a specific number" (page 506), which is unclear to us. There is no similarities analysis between the study groups after the allocation for treatment. The study group had vaporization of the entire transformation zone, distal endocervical canal and "brushing" of the cervix portio while the control group received no treatment. It was not possible to blind the procedure being studied to patients and investigators. After 18 months, $8(5.6 \%)$ women from the treatment group and $24(7.7 \%)$ of the control group showed progression to pre- invasive disease $(P=0.42)$. No data was presented on the disappearance of the disease.

\section{Ruge et al., 1992.}

In this study 50 women with biopsy-proven HPV infection with or without concomitant CIN I were randomly allocated to a laser group or a control group. There is no information about the randomization method used. However, despite this limitation, there were no statistical differences between study and control groups in age, smoking, socioeconomic status, sexual habits and contraceptive methods. The treatment group had their entire transformation zone "evaporated" to a depth of 4-5 $\mathrm{mm}$. The control group had no treatment. As in the previous study, there was no patient or

Table 4 - Included studies

\begin{tabular}{ll} 
Author, publication year & Patients selected \\
\hline $\begin{array}{l}\text { Boothby et al., }{ }^{19} 1990 . \\
\text { Diakomanolis et al., }{ }^{20} 1990 .\end{array}$ & HPV infection without CIN \\
Ruge et al., ${ }^{21} 1992$. & HPV infection without CIN \\
Hording et al., ${ }^{22} 1993$. & HPV infection with or without CIN I \\
Fairley et al., ${ }^{23} 1996$. & HPV infection without CIN * IN I
\end{tabular}

\section{Treatment method tested}

$50 \%$ trichloroacetic acid application

$\mathrm{CO}_{2}$ laser vaporization of the entire transformation zone, distal region of the endocervical canal and, more superficially, the ectocervical region outside the transformation zone. $\mathrm{CO}_{2}$ laser vaporization of the entire transformation zone and adjacent areas to $4-5 \mathrm{~mm}$ in depth.

$\mathrm{CO}_{2}$ laser vaporization of the entire transformation zone. Beta-carotene, $30 \mathrm{mg} /$ day, taken orally for one year.

* 0 ther groups were selected, with CIN I to CIN III, but these data were not used in our review. 
investigator blinding regarding which group each patient was allocated to. After 12 months, the authors analyzed regression, persistence and progression and found no statistical differences between the two groups.

\section{Hording et al., 221993.}

In this study, the authors analyzed 46 women with biopsy-proven HPV cervical infection with or without CIN I. These women were allocated randomly to a treatment group (laser vaporization of the cervix) or to a control group without treatment. The authors did not report the randomization method used and there is no analysis of group similarities after treatment allocation. As in the two previous studies, there was no patient or investigator blinding concerning treatment or control procedures. No patients were lost to follow-up, with mean follow-up of 28 months (range of 12 to 54 months). There were no significant differences between the study groups.

\section{Fairley et al., 1996.}

Considering epidemiological and laboratory evidence that beta carotene may be of value in the treatment of pre-invasive cervical disease, these authors performed a double-blind clinical trial in which 117 women were randomly allocated to receive beta carotene (30 $\mathrm{mg} /$ daily) or placebo (lecithin, $400 \mathrm{mg} /$ daily) for one year. There is no report of the randomization method used but the groups were similar in age, marital status, smok- ing, contraceptive method, parity and number of sexual partners. After one year of follow-up no differences were found between the study groups in terms of lesion clearance. Thirteen per cent of the women receiving betacarotene noticed yellowing of the skin.

\section{Information extracted from the selected studies}

Table 5 shows data extracted from the selected studies concerning progression of HPV infection without CIN to presence of CIN or from HPV with CIN I to higher grades of CIN. Table 6 shows data related to disappearance of subclinical HPV with or without CIN I.

Three studies included an analysis of the presence of HPV-DNA and its disappearance after the experimental period. These data are shown in Table 7.

\section{DISCUSSION}

From the 59 studies identified, obtained and reviewed, only five met the inclusion criteria. None of these found any difference between treatment and control groups in either progression or regression of subclinical HPV infection of the cervix. However, these studies were limited by one or more problems, such as the sample size, difficulties in blinding patients and investigators, and we do not know the randomization method used by four of them. These limitations leave us unsure that the treatments tested are ineffective.

Most studies identified were excluded because

Table 5 - Progression of HPV infection with or without CIN I

\begin{tabular}{lcccccc}
\hline $\begin{array}{l}\text { Author, } \\
\text { year }\end{array}$ & $\begin{array}{c}\text { Experimental } \\
\text { group (n) }\end{array}$ & $\begin{array}{c}\text { Progression } \\
\mathbf{n}(\%)\end{array}$ & $\begin{array}{c}\text { Control } \\
\text { group (n) }\end{array}$ & $\begin{array}{c}\text { Progression } \\
\text { n (\%) }\end{array}$ & P-value & Follow-up \\
\hline Diakomanolis et al., ${ }^{20} 1990$ & 142 & $8(5.6 \%)$ HPV to CIN I-III & 310 & $24(7.7 \%)$ HPV to CIN I-III & 0.42 & 18 months \\
Ruge et al., ${ }^{21} 1992$ & 25 & $2(8 \%)$ HPV-CIN I to CIN III & 25 & $2(8 \%)$ HPV-CIN I to CIN III & 0.60 & 12 months \\
\hline
\end{tabular}

Table 6 - Regression of HPV infection with or without CIN I

\begin{tabular}{|c|c|c|c|c|c|c|}
\hline $\begin{array}{l}\text { Author, } \\
\text { year }\end{array}$ & $\begin{array}{l}\text { Experimental } \\
\text { group (n) }\end{array}$ & $\begin{array}{c}\text { Disappearance } \\
\text { or regression of HPV } \\
\text { subdinical lesionsn (\%) }\end{array}$ & $\begin{array}{l}\text { Control } \\
\text { group (n) }\end{array}$ & $\begin{array}{c}\text { Disappearance } \\
\text { or regression of HPV } \\
\text { subdinical lesions n(\%) }\end{array}$ & P-value & Follow-up \\
\hline Boothby et al., ${ }^{19} 1990$ & 15 & $1(6.7 \%)$ & 15 & $3(20 \%)$ & 0.52 & 4 months \\
\hline Ruge et al., ${ }^{21} 1992$ & 25 & $21(84 \%)$ & 25 & $19(76 \%)$ & 0.48 & 12 months \\
\hline Hording et al., ${ }^{22} 1993$ & 23 & $21(91.3 \%)$ & 23 & $16(69.5 \%)$ & 0.11 & 12 to 54 months \\
\hline Fairley et al., ${ }^{23} 1996$ & 33 & $20(60.6 \%)$ & 36 & $22(61.1 \%)$ & 0.96 & 12 months \\
\hline
\end{tabular}

Table 7 - HPV-DNA detection in the selected studies

\begin{tabular}{ll}
\hline Author, year & HPV-DNA analysis \\
\hline Ruge et al. ${ }^{21} 1992$ & HPV-16 DN A detected by PCR, before and after the study period. There was no difference between the success rate \\
of the HPV + laser treatment group $(78.5 \%)$ compared to the control group $(80 \%)$ in achieving HPV-16-DN A disappearance. & $\begin{array}{l}\text { HPV } 6,11,16,18 \text { and } 33 \text { detected by PCR before and after the study period. There was a significant statistical } \\
\text { difference between the HPV + laser treatment group }(12 / 13,92 \%) \text { and control group }(2 / 7,29 \%, p=0.007) .\end{array}$ \\
Hording et al. ${ }^{22} 1993$ & $\begin{array}{l}\text { HPV-DN A detected by PCR or Hybrid Capture. There was no difference in the detection of HPV-DN A between } \\
\text { treatment and control groups. }\end{array}$
\end{tabular}


of lack of internal validity for adequately testing any form of treatment.

Although we could not obtain 8 studies in their full version, even after attempts using national or foreign libraries and asking the authors for them (in the case of studies identified in Books of Abstracts from medical meetings), assessment of their abstracts allowed us to conclude that they would probably be excluded because they were not clinical trials.

In the decision-making process concerning the use of any therapy to treat this kind of HPV infection, we must consider the lack of evidence that treatment is better than no treatment. The use of therapies in which efficacy is not proven can lead to unnecessary waste of money or can be worse than the illness itself, considering the physical consequences of some of them and the psychological consequences of trying to treat an infection that can present recurrence.

Well-conducted randomized clinical trials can be expected to prove some therapy to be effective against subclinical HPV infection, preferably with patient and investigators being blinded, and with sufficient sample size with enough power to avoid beta error (i.e. saying that there is no difference between treatment and no treatment when it actually exists and the only reason that statistical significance was not achieved was because of the small sample size).

However, applying financial resources to conduct an experiment to clarify this question appear unreason- able to us. Given the high prevalence reported by some authors, varying between 13 to $20 \%$ in developing countries, in which Brazil is included, ${ }^{76}$ and the transient characteristic of most of these infections, ${ }^{77}$ the cost of medicine usage, therapeutic procedures or vaccines would not be reasonable in the prevention of cervical cancer.

On the other hand, there is al ready strong evidence of efficacy in treatment of pre-invasive diseases in order to prevent cervical cancer. It seems to us that it is more cost-effective to apply these procedures to the patients that present $\mathrm{CIN} \mathrm{II/II,} \mathrm{considering} \mathrm{that}$ they are a small proportion of all HPV-infected women.

\section{CONCLUSIONS}

The evidence we found for efficacy in treatment of subclinical HPV infection of the cervix without CIN was unsatisfactory. However, considering the limitations of the selected studies, particularly in terms of sample size, possible efficacy in these treatments cannot be excluded.

In many of the studies excluded for methodological reasons, the authors' conclusion was clearly in favor of the treatments tested, possibly leading to ineffective or even potentially harmful therapies and to unnecessary costs.

Medline, LILACS and Excerpta Medica were the most useful sources of references, and identified all of the studies included.

\section{REFERENCES}

1. Reid R, StanhopeCR, Herschman BR, Booth E, Phibbs GD, SmithJP. Genital warts and cervical cancer: I. Evidence of an association between subclinical papillomavirus infection and cenvical malignancy. Cancer 1982;50:377-87.

2. Guyatt GH, Sackett DL, Cook DJ. Users' guides to the medical literature. II. How to use an article about therapy or prevention. A. Are the results of the study valid? JAMA 1993;270(21):2598-601.

3. Petitti DB. Meta-analysis, Decision analysis and cost-effectiveness analysis - methods for quantitative synthesis in medicine. Oxford: Oxford University Press 1994.

4. Guyatt GH, Rennie D. Users' guides to the medical literature [editorial]. JAMA 1993;270(17):2096-7.

5. Cohen J. A coefficient of agreement for nominal scales. Educ Psychol Measur 1960;20:37-46.

6. Bartko JJ, Carpenter WT. On the methods and theory of reliability. J Nerv Ment Dis 1976;163(5):307-17

7. Landis JR, Koch GG. The measurement of observer agreement for categorical data. Biometrics 1977;33:159-74.

8. Dunn G, Everitt B. Clinical biostatistics: an introduction to evidence-based medicine. New York: John Wiley \& Sons; 1995.

9. Gori J, Castano R, Dominguez J, et al. Laser vaporization, cryotherapy and trichloroacetic acid application in the therapy of ectocenvical condylomatous lesions: a comparison of clinical results. Cervix 1992;10(4):217-9.

10. Madej J, Basta A, Madej Jr JG, Strama M. Colposcopy staging and treatment of papillomavirus infection of the cervix. Clin Exp Obstet Gynecol 1992;19(1):34-9.

11. Minucci $D$, Cinel $A$, Insacco $E$. Diathermic loop treatment for $C I N$ and HPV lesions. A follow-up of 130 cases. Eur J Gynecol Oncol 1991;12(5):385-93.

12. Naud $P$, Monego $H$, Ricco $L$, Catalan F. $O$ uso de nitrogênio líquido na terapêutica do papilomavirus humano (HPV) com confirmação por hibridização molecular. XV Brazilian Congress of Gynecology and Obstetrics; 1989 (Book of Abstracts).

13. Pietroluongo A, Pereira Filho A, Levente $A$. Tratamento das viroses pelo papilomavirus humano (HPV) com vacina BCG. XV Brazilian Congress of Gynecology and Obstetrics; 1989 (Book of Abstracts).

14. Salvo A, Rojas I, Figueiroa L, Stuardo P. Imunoterapia por via cutanea con dinitroclorobenceno en infeccion del cuello uterino por virus papiloma. Rev Child Obstet Ginecol 1991;56(6):460-3.

15. Torrisi A, Cinel A, Wittemberg L, Minucci D. Therapy with B-interferon cream in the cervical-vaginal infections by Human papilloma virus (HPV). Eur J Gynecol Oncol 1987;7(4-5):441.

16. Trofatter Jr. Interferon treatment of anogenital papillomavirus-related diseases. Dermatol Clin 1991;9(2):343-52.

17. Yliskoski M, Syrjänen $K$, Syrjänen $S$, Saarikoski S, Nethersell A. Systemic alpha-interferon (Wellferon) treatment of genital Human papillomavirus (HPV) Type 6,11,16 and 18 infections: a double-blind, placebo-controlled trial. Gynecol Oncol 1991;43:55-60.

18. Woodman CBJ, Byrne P, Kelly KA, Hilton C. A randomized trial of laser 
vaporization in the management of cervical intraepithelial neoplasia associated with Human papillomavirus infection. J Public Health Med 1993;15(4):327-31.

19. Boothby RA, Carlson JA, Rubin M, Morgan M, MikutaJJ. Single application treatment of human papillomavirus infection of the cervix and vagina with trichloroacetic acid: a randomized trial. Obstet Gynecol 1990;76(2):278-80.

20. Diakomanolis E, Rodolakis A, Simiakaki H, Frangopoulou E, Efstratiadou $M$. Randomized control trial of laser vaporization in the management of Human papillomavirus infection in the uterine cervix. Rec Adv Cerv Pathol Colposc, 1990;3:505-10.

21. Ruge S, Felding C, Skouby SO, Lundvall F, Hording U, Norrild B. $\mathrm{CO}_{2}$ laser vaporization in the treatment of cervical Human papillomavirus infection in women with abnormal Papanicolaou smears. Gynecol Obstet Invest 1992;33(3):172-6.

22. Hording U, Rygaard C, Ruge S, Felding C, Lundvall F, Junge J. Cervical koilocytosis and high risk HPV types: the benefit of laser vaporization. Eur J Obstet Gynecol Reprod Biol 1993;51(2):125-30.

23. Fairley CK, Tabrizi SN, Chen S, et al. A randomized trial of beta-carotene vs. placebo for the treatment of cervical HPV infection. IntJ Gynecol Cancer 1996;6:225-30.

24. Ali SW, Evans AS, Monaghan JM. Results of $\mathrm{CO}_{2}$ laser cylinder vaporization of cervical intraepithelial disease in 1234 patients. An analysis of failures. Br J Obstet Gynecol 1986:93(1):75-8.

25. Baggish MS. Treating viral venereal infection with the $\mathrm{CO}_{2}$ laser.J Reprod Med 1982;27(12):737-42.

26. Benrubi G, Nuss RC, Holmes K, Lammert N. Efficacy of cryotherapy in the treatment of human papillomavirus infection of the uterine cervix. J Fla Med Assoc 1986;73(3):188-91.

27. Benrubi GI, Shannon J, Glazer J, Nuss RC. Cervical human papilloma virus infection: is treatment possible? J Fla Med Assoc 1988;75(12):799-800.

28. Boothby RA, Benrubi GI, Nuss RC, Lammert N. Laser treatment of Human papillomavirus infections of the uterine cervix. Colposc Gynecol Laser Surg 1986;2(1):25-9.

29. Brodman M, Dottino P, Friedman JrF, Heller D, Bleiweiss I, Sperling R Human papillomavirus-associated lesions of the vagina and cenvix. Treatment with a laser and issueal 5-fluorouracil. J Reprod Med 1992;37(5):453-6.

30. Caballero F, Baez J, Troya Cl. La crioterapia en el tratamiento de las lesiones premalignas del cervix uterino. Rev Med Caja Seguro Social $1985 ; 17(2): 140-3$.

31. Cinel $A$, Wittenberg $L$, Minucci $D$. B-interferon issueal treatment in low and high-risk cervical lesions. Clin Exp Obstet Gynecol 1991;18(2):91-7.

32. Costa S, Poggi MG, Palmisano L, Syrjänen S, Yliskoski M, Syrjänen K. Intramuscular ß-interferon treatment of Human papillomavirus lesions in the lower female genital tract. Cervix 1988;6:203-12.

33. das Dores GB, Martins NV, Focchi J, et al. Tratamento da infecção cérvicovaginal por papilomavirus humano HPV com quatro fármacos. J Bras Ginecol 1993;103(6):205-10.

34. das Dores GB, Ribalta JCL, Martins NV, et al Tratamento da infecção do colo uterino por papilomavirus humano com interferon gel. Rev Paul Med 1991;109(4):179-83.

35. Davila GW, Shroyer KR. Issueal 5-fluorouracil in the treatment of cervical Human papillomavirus infection. Gynecol Obstet Invest 1996;41(4):275-7.

36. Diakomanolis E, Rodolakis A, Dailianas S, Kalpaktsogiou K, Sakellaropoulos G, Aravantinos D. Long term results of $\mathrm{CO}_{2}$ laser treatment of low-grade squamous intraepithelial lesions. Cervix 1995;13:149-52.

37. Evans AS, Monaghan JM, Beattie AB. Carbon dioxide laser treatment of cervical warty atypias. Gynecol Oncol 1984;17:296.

38. Gal D, Friedman M, Mitrani-Rosenbaum S. Transmissibility and treatment failures of different types of human papillomavirus. Obstet Gynecol
1989;73(3 Pt 1):308-11.

39. Gall SA, Constantine L, Koukol D. Therapy of persistent human papillomavirus disease with two different interferon species. Am J Obstet Gynecol 1991;164(1):130-4.

40. Gonzalez-Sanchez JL, Celis C, Rodriguez-de-Santiago JD, Pena-Sandoval $M$, Menendez-Velasquez J. Tratamiento del virus del papiloma humano (VPH) del cervix con criocirugia. Ginecol Obstet Mex 1991;59:164-8.

41. Husseinzadeh N, Guoth JG, Jayawardena DS. Subclinical cervicovaginal human papillomavirus infections associated with cervical condylomata and dysplasia. Treatment outcomes. J Reprod Med 1994;39(10):777-80.

42. Klutke JJ, Bergman A. Interferon as an adjuvant treatment for genital condyloma acuminatum. Int J Gynecol Obstet 1995;49:171-4.

43. Lira Neto JB, Santos JF, Vieira IM. Infecção ginecológica pelo vírus do condiloma. Contribuição ao diagnóstico e terapêutica. J Bras Ginecol 1984;94:295.

44. Luesley MD, Cullimore J, Redman CWE, et al. Loop diathermy excision of the cenvical transformation zone in patients with abnormal cervical smears. BMJ 1990;300:1690-3.

45. Maldonado P, Christo Jr WG, Mannarino MPB. Ensaio terapêutico com Thuya occidentalis em pacientes portadoras de infecção pelo HPV no trato genital inferior. Annals of the IX Brazilian Congress of Cervical Pathology and Colposcopy; 1992.

46. Maldonado P, Christo WG, Costa CM, Pollastri CE, Cavalcanti RMVF, Pereira NA. Conduta nas infecções cervicovaginais pelo HPV no IG UFRJ. Femina 1991;19:324.

47. Malviya VK, Deppe G, Pluszczynski R, Boike G. Trichloroacetic acid in the treatment of human papillomavirus infection of the cervix without associated dysplasia. Obstet Gynecol 1987;70:72-4.

48. Markowska J, Nowak M, NiecewiczR, BreborowiczJ, Wiese E, Zengteler $\mathrm{G}$. Results of issueal treatment of HPV infection in the uterine cervix using interferon beta, 13-cis-retinoic acid and TFX. Eur J Gynecol Oncol 1994;15(1):65-9.

49. Menendez-VelazquezJF, Gonzalez-SanchezJL, Rodriguez-de-Santiago JD, Munoz-Reyes R, Bailon-Uriza R. Tratamiento de la infeccion cervical por el virus del papiloma humano (VPH) con acido tricloroacetico. Ginecol Obstet Mex 1993;61:48-51.

50. Merkur H, Baird PJ. Papillomavirus infection of the female genital tract before and after treatment: a cytological, colposcopic and histological study. Aust N ZJ Obstet Gynecol 1989;29(3 Pt 1):185-8.

51. Milla-Villeda RH, Gurrola-Medrano T. Tratamiento de la infeccion cervical subclinica por el virus del papiloma humano (VPH) con asa diatermica. Eficacia a corto plazo. Ginecol Obstet Mex 1995;63:293-6.

52. Mitchell H, Medley G. Evidence against diathermy as a beneficial treatment for HPV infection of the cervix. Aust N Z J Obstet Gynecol 1989;29(4):439-42.

53. Mohanty KC, Lowe JW. Cryotherapy in the management of histologically diagnosed subclinical HPV infection of the cervix. Br J Clin Pract 1990;44(12):574-7.

54. Mohanty KC, Lowe JW. Cold coagulation therapy in the treatment of histologically diagnosed subclinical human papillomavirus infection of the cervix. Br J Clin Pract 1991;45(2):102-4.

55. Nieminen $P$, Aho $M$, Lehtinen $M$, Vesterinen $E$, Vaheri $A$, Paavonen J. Treatment of genital HPV infection with carbon dioxide laser and systemic interferon alpha-2b. Sex Transm Dis 1994;21(2):65-9.

56. Puttemans $P$, van Pelle Y, De Muylder E. Carbon dioxide laser vaporization of cervical subclinical papillomaviral infection neoplasia: short-term effectiveness. Eur J Obstet Gynecol Reprod Biol 1986;23:167-80.

57. Qian ZW, Mao SJ, Cai XC, et al. Viral etiology of chronic cervicitis and its therapeutic response to a recombinant interferon. Chin Med J 1990;103(8): 647-51. 
58. Riva JM, Sedlacek TV, Cunnane MF, Mangan CE. Extended carbon dioxide laser vaporization in the treatment of subclinical papillomavirus infection of the lower genital tract. Obstet Gynecol 1989;73(1):25-30.

59. Rogstad KE, Dixon CA, Ahmed IH. The management of subclinical wart virus infection of the cervix in a genitourinary clinic. Geniturin Med 1992;68(5):307-8.

60. Ruge S, Felding C, Skouby SO, Lundvall F, Hording U. $\mathrm{CO}_{2}$ laser vaporization of human papillomavirus (HPV)-induced abnormal cervical smears. A simple and effective solution to a recurrent clinical problem. Clin Exp Obstet Gynecol 1991;18(2):99-101.

61. Schneider A, Papendick U, Gissmann L, De Villiers E-M. Interferon treatment of human genital papillomavirus infection: importance of viral type. Int J Cancer 1987;40:610-4

62. Semprini AE, Stillo A, Marcozzi S, Castagna C, Fiore S, Radaelli U. Treatment with interferon for genital HPV in HIV-positive and HIVnegative women. Eur J Obstet Gynecol Reprod Biol 1994;53(2):135-7.

63. Sesti F, De-Santis L, Farne C, Mantenuto L, Piccione E. Efficacy of $\mathrm{CO}_{2}$ laser surgery in treating squamous intraepithelial lesions. An analysis of clinical and virologic results. J Reprod Med 1994;39(6):441-4.

64. Stefanon D. Activity of interferon-ß in small condylomatous lesions of the uterine cervix. Cervix 1983;1:23-6.

65. Stentella P, Frega A, Di-Renzi F, Palazzetti PL, Pachi A. Issue and systemic administration of natural alpha interferon in the treatment of female and male HPV genital infections. Clin Exp Obstet Gynecol 1996;23(1):29.

66. Strand A, Wilander E, Zehbe I, Rylander E. High risk HPV persists after treatment of genital papillomavirus infection but not after treatment of cervical intraepithelial neoplasia. Acta Obstet Gynecol Scand 1997;76(2):140

67. Surwit EA, Grahan V, Droegemueller W, et al. Evaluation of issueally applied trans-retinoic acid in the treatment of cervical intraepithelial

\section{esu mo}

CONTEXTO: 0 tratamento da infecção subclínica pelo papilomavírus humano (HPV) no colo uterino é controverso.

OBJETVO: Avaliar a eficácia de alguma terapia para infecção pelo HPV no colo uterino sem neoplasia intraepitelial.

MÉTODO: Realizamos uma revisão sistemática com uma busca abrangente de estudos no M edline, LLACS, Excerpta medica, AIDSUN E, Popline, Cochrane Library e listas de referências de outros autores para identificar estudos experimentais sobre terapia para a infecção subclínica pelo HPV sem neoplasia intraepitelial no colo uterino. Para identificar artigos não publicados, também contactamos especialistas da área, registros de ensaios clínicos, indústrias farmacêuticas, instituições governamentais e de fomento à pesquisa. Também procuramos por estudos através da Internet e em livros de abstracts de alguns eventos médicos. 0 s estudos identificados foram mascarados e selecionados por critérios de inclusão que auxiliaram a garantir sua validade interna. 0 s dados sobre regressão ou progressão da infecção pelo HPV foram extraídos dos estudos incluídos.

RESULTADOS: Identificamos 67 estudos relacionados ao tratamento da infecção subclínica pelo HPV sem neoplasia intraepitelial do colo uterino (N IC ). A penas cinco ensa ios clínicos atenderam a os critérios de inclusão e nenhum demonstrou diferenças significativas entre 0 grupo em teste e 0 grupo-controle no que se refere a regressão da infecção pelo HPV (com ou sem N IC I) ou progressão para graus mais altos de N IC

CONCLUSÃO: As evidências de eficácia de alguma terapia para infecção subclínica pelo HPV sem neoplasia intraepitelial no colo uterino encontradas na literatura médica foram insatisfatórias.

PALAVRAS-CHAVE: HPV. N eoplasia Intraepitelial Cervical. Tratamento. Revisão sistemática lesions. Am J Obstet Gynecol 1982;143(7):821-3.

68. Villani C, Nobili F, Stentella P, Pace S. The viral lesion (HPV) of the lower genital tract in teenagers: clinical and therapeutic aspects. Eur J Gynecol Oncol 1989;10(4):267-71.

69. Villani $C$, Vecchione A, Pace S, Carenza L. The rationale for treatment of cervical lesions (HPV +/- CIN). Clin Exp Obstet Gynecol 1989;16(1):44-7.

70. Ward BG, Thomas IL. Randomized prospective intervention study of Human cervical wart virus infection. Aust N Z J Obstet Gynecol 1994;34(2):182-5.

71. WeckPK, Buddin DA, Whisnant JK. Interferon in the treatment of genital Human papillomavirus infections. Am J Med 1988;85(Suppl 2A):159-64.

72. Winceslaus SJ, Brown C, Goh BT. Managing women with human papillomavirus changes in cervical cytology. Genitourin Med 1988;64(4):259-62.

73. Yliskoski M, Saarikoski S, Syrjänen K, Syrjänen S, Castrén 0 . Cryotherapy and $\mathrm{CO}_{2}$ laser vaporization in the treatment of cervical and vaginal HPV infections. Acta Obstet Gynecol Scand 1989;68(7):619-25.

74. Zarcone R. Treatment of genital HPV-infections with natural alpha interferon from normal human leukocytes. Clin Exp Obstet Gynecol 1995;22(1):14-9.

75. Zarcone R, Bellini P, Cardone G, Cardone A. Treatment of cervix condylomata with alpha-IFN leucocytar. Clin Exp Obstet Gynecol 1995;22(4):326-9.

76. Bosch FX, Manos MM, Munoz $\mathrm{N}$ et al. Prevalence of human papillomavirus in cervical cancer: a worldwide perspective. J Natl Cancer Inst, 1995;87:796-802.

77. Villa LL. Human papillomaviruses and cervical cancer. Adv Cancer Res, 1997;71:321-41.

\section{publishing information}

\section{Acknowledgement}

To Francisco Xavier Bosch, who kindly revised the manuscript and contributed to its reinforcement.

Fábio Russomano, MSc. Department of Gynecology, Instituto Fernandes Figueira, Fundação Oswaldo Cruz, Rio de Janeiro, Brazil.

Aldo Reis, PhD. Clinical Epidemiology Program at UFRJ, Rio de Janeiro, Brazil.

Maria José de Camargo, MSc. Department of Gynecology, Instituto

Fernandes Figueira, Fundação Oswaldo Cruz, Rio de Janeiro, Brazil.

Maria Virgínia Peixoto Dutra, MSc. Epidemiology Service, Instituto

Fernandes Figueira, Fundação Oswaldo Cruz, Rio de Janeiro, Brazil.

Sandra Costa Fonseca, MSc. Leila Diniz Obstetric Unit (Brazilian Health

Ministry), Rio de Janeiro, Brazil.

Jean Anderson, MD. The Johns Hopkins University AIDS Service, Baltimore,

Maryland, USA.

Sources of funding: Not declared

Conflict interest: Not declared

Last received: 03 January 2000

Accepted: 03 January 2000

\section{Address for correspondence:}

Fábio Russomano

Av. João Carlos Machado, 380/308 - Barra da Tijuca

Rio de Janeiro/RJ - Brasil - CEP 22620-080

E-mail: fabiorussomano@montreal.com.br 